\title{
Primary headache - causes and differential diagnosis
}

Pierwotny ból głowy - przyczyny i różnicowanie

\author{
'Science Students' Association, Department of Pathophysiology and Endocrinology, Faculty of Medical Sciences in Zabrze, Medical University of Silesia in Katowice, Zabrze, Poland \\ ${ }^{2}$ Dental Centre "Centrum Przyjaznej Stomatologii New-Dent," Chorzów, Poland \\ ${ }^{3}$ Department of Pathophysiology and Endocrinology, Faculty of Medical Sciences in Zabrze, Medical University of Silesia in Katowice, Zabrze, Poland \\ Correspondence: Aleksandra Nowak, DDS, Department of Pathophysiology and Endocrinology, Faculty of Medical Sciences in Zabrze, Medical University of Silesia in Katowice, Traugutta 2, 41-800 Zabrze, Poland, \\ e-mail:a.nowakk0208@gmail.com
}

\begin{abstract}
It is estimated that $30-80 \%$ of the population in Europe and the United States experience frequent and recurrent headaches, the most common of which are tension-type, migraine and cluster headaches. Migraine can also overlap with tension-type headache, which is referred to as vasomotor or mixed headache. According to the $3^{\text {rd }}$ edition of the International Classification of Headache Disorders (ICHD-3 beta), these entities are classified as idiopathic (primary) headaches, where pain is both the essence and the main symptom of the disease. Idiopathic headaches are difficult to diagnose as they differ mainly in intensity. When collecting medical history, the focus should be placed on the duration and location of pain. Therefore, a thorough interview to assess subjective pain intensity is one of the basic elements of the diagnostic workup. Tension-type headache, migraine and cluster headaches are also characterised by specific symptoms, identification of which is essential for the diagnosis. Cluster headache produces the most typical symptoms. Since these types of headaches require different therapeutic strategies, it is necessary to differentiate them. Their treatment requires interdisciplinary cooperation of, among others, dentists, neurologists, and physiotherapists. In this paper, we made an attempt to discuss the pathogenesis, symptoms and differential diagnosis of tension headache, migraine and cluster headache, based on literature review.
\end{abstract}

Keywords: tension headache, migraine, cluster headache, pathogenesis, symptoms

Streszczenie U 30-80\% populacji w Europie i Stanach Zjednoczonych występują częste i nawracające bóle głowy, spośród których najczęstsze są bóle: napięciowy, migrenowy i klasterowy. Migrena może też występować jednocześnie z bólem napięciowym w takiej sytuacji mówimy o bólu naczynioruchowym lub bólu mieszanym. Schorzenia te według Międzynarodowej Klasyfikacji Bólów Głowy (The International Classification of Headache Disorders, $3^{\text {rd }}$ edition, ICHD-3 beta) klasyfikowane są jako samoistne (pierwotne) bóle głowy - ból stanowi istotę choroby i jej główny objaw. Diagnostyka idiopatycznych bólów głowy jest trudna, ponieważ różnią się one od siebie głównie natężeniem. W trakcie zbierania wywiadu należy zwrócić uwagę przede wszystkim na czas trwania oraz lokalizację bólu. W związku z tym jednym z podstawowych elementów diagnostycznych jest wnikliwy wywiad, który ocenia subiektywne doznania bólowe. Zarówno napięciowy, migrenowy, jak i klasterowy ból głowy cechują się również objawami dla nich specyficznymi, których rozpoznanie jest niezbędne dla ustalenia diagnozy. Najbardziej charakterystyczne objawy towarzyszą klasterowemu bólowi głowy. Ze względu na fakt, że wymienione rodzaje bólów głowy wymagają odrębnego postępowania leczniczego, niezbędne jest ich różnicowanie. W ich leczeniu konieczna jest interdyscyplinarna współpraca między innymi lekarzy stomatologów, neurologów i fizjoterapeutów. W niniejszej pracy na podstawie piśmiennictwa podjęto próbę przedstawienia zarówno patogenezy, objawów, jak i diagnostyki różnicowej napięciowego bólu głowy, migreny oraz klasterowego bólu głowy.

Słowa kluczowe: napięciowy ból głowy, migrena, klasterowy ból głowy, patogeneza, objawy 


\section{INTRODUCTION}

$\mathrm{E}$ pidemiological data show that $30-80 \%$ of the population in Europe and the United States experience frequent and recurrent headaches ${ }^{(1,2)}$, with tension-type headache (TTH), migraine and cluster headache, which belongs to the trigeminal autonomic cephalalgias (TAC), being the most common forms. Each of these conditions has been divided into several subtypes based on appropriate criteria. According to the $3^{\text {rd }}$ edition of the International Classification of Headache Disorders (ICHD-3 beta), these headaches are classified as idiopathic (primary) headaches, where the pain is both the essence and the main symptom of the disease $\mathrm{e}^{(3)}$. As estimated by various authors, the mean incidence of migraine in the general population ranges from $2-3 \%^{(4,5)}$ to up to $20 \%^{(6,7)}$, with women more likely to be affected than men $(3: 1)^{(4)}$; the incidence of tension-type and cluster headache is $30-80 \%{ }^{(8)}$ and $<1 \%{ }^{(9)}$, respectively. Migraine can also overlap with TTH, which is referred to as vasomotor or mixed headache. Idiopathic headaches are difficult to diagnose as they differ mainly in severity rather than qualities. Since these types of headaches require different treatment strategies, it is necessary to differentiate them. We made an attempt to discuss the pathogenesis, symptoms and differential diagnosis of tension-type headache, migraine and cluster headache, based on literature review.

\section{THE PATHOGENESIS OF TENSION-TYPE HEADACHE}

Attempts have been made to explain the pathomechanism of TTH using the biopsychosocial model. All groups of factors (biological/physiological and psychological/social) in this model are equally important and are subject to mutual influences. The model assumes the levels of the pain process. Neurophysiological processes make up the central level. The secretory, immune and autonomic systems are considered peripheral systems. The psychosocial sphere includes the processes of cognitive assessment and emotional responses to situations that modify the course of physiological processes at both the central and peripheral levels ${ }^{(10)}$. Central nervous system (CNS) activity at the central level may influence or be a source of muscle pain. It is a consequence of continuous secondary pulsation related to deep pain as a result of an elevated level of emotional tension (excitation of the autonomic system) or as a result of changes in the descending inhibitory pain system. CNS phenomena excite the peripheral sensory neurons and cause antidromic release of allogenic substances to peripheral tissues, thereby inducing pain ${ }^{(7)}$. Central excitation effects can also induce motor effects (through efferent neurons), causing muscle contractures ${ }^{(10)}$. Research suggests an important role of psychological factors in the pathogenesis of TTH. Torelli et al. have shown that patients with TTH are more likely to experience negative automatic thoughts (as in depression), are characterised by a lower ability to recognise emotions and achieve lower assertiveness scores, with a correlation between the intensity of their negative automatic thoughts and the frequency of $\mathrm{TTH}^{(11)}$. Researchers also suggest that prolonged attention and concentration efforts, as well as emotional tension may be considered as psychological triggers $^{(8)}$.

\section{THE PATHOGENESIS OF MIGRAINE HEADACHE}

Several pathogenetic theories have been proposed for migraine pain. Despite confirmed genetic predisposition to migraine, especially the one with aura, there are many environmental and pathological factors, such as atherosclerosis and temporal arteritis, that also contribute to this type of headache ${ }^{(12,13)}$.

The genetic aetiology of migraine has been confirmed in studies in families with familial hemiplegic migraine (FHM). The presence of genes associated with ion channels, and thus impaired membrane excitability, is the likely pathogenetic factor. Half of the cases of FHM are caused by a mutation in the CACNA1A gene, which encodes the Cav2.1 P/Q voltage-dependent calcium channel (FHM 1). Mutations in the ATP1A2 gene for $\mathrm{Na}^{+} / \mathrm{K}^{+}$ATPase (FHM 2) account for $20 \%$ of FHM cases. The FHM 3 subtype is caused by mutations in SCN1A encoding the neural $\mathrm{Na}^{+}$ channel $^{(11,14,15)}$. Other researchers emphasise the pathogenetically important role of the $H E P H$ (responsible for iron transport and homeostasis) and KCNK18 (responsible for potassium transport and homeostasis) genes ${ }^{(16)}$. Epidemiological studies also confirmed the predisposition to migraine with aura in individuals with a mutation of the C677T gene encoding methylenetetrahydrofolate reductase $^{(12)}$.

Disturbed cerebral blood flow during a migraine attack indicates a vascular aetiology. The aura, which occurs as a result of contraction of the arteries arising from the internal carotid artery, leading to ischemia of important brain regions followed by arterial relaxation and pulsation, occurs in the first stage ${ }^{(17)}$. Mechanical arterial deformation stimulates nociceptors and afferent fibers within vascular and perivascular tissues. The pain caused by disrupted cerebral blood flow is throbbing and often accompanied by vegetative symptoms such as lacrimation, photosensitivity, and nausea. The last stage involves perivascular oedema and postictal symptoms ${ }^{(13)}$. The fact that migraine is more common in patients with cardiovascular diseases, such as atherosclerosis or temporal arteritis, may be evidence for the vascular theory ${ }^{(17)}$.

According to the neurogenic theory, an inhibition of cortical activity is responsible for aura, whereas vasomotor disorders are of a secondary nature ${ }^{(13)}$.

During headache, aseptic inflammation of the trigeminal nerve is also observed, as a result of which pro-inflammatory substances and neuropeptides (substance P, neurokinin 
A, calcitonin gene-related peptide - CGRP) are released from its sensory endings, which promotes meningeal expansion and permeability, and the development of an inflammatory reaction ${ }^{(18,19)}$.

According to another (biochemical) theory, serotonin, which by binding to the $5-\mathrm{HT} 1 \mathrm{~B} / \mathrm{D}$-receptor also maintains vascular wall tension, is responsible for the central perception of pain. Its reduced serum levels cause relaxation and pulsation of the arterial walls, and an increase in their permeability to pain-promoting cytokines ${ }^{(13,18)}$. It has also been shown that migraine symptoms can be induced by dopaminergic stimulation. Dopamine receptor hypersensitivity has been shown in migraine patients. Co-administration of dopamine receptor antagonists with other anti-migraine drugs increases the efficacy of antimigraine treatment. According to the biochemical theory, migraine is a primary CNS disease, while impaired cerebral perfusion is of a secondary nature. However, further research is needed to elucidate the pathomechanism of aura and the postictal phase $\mathrm{e}^{(20-22)}$.

\section{THE PATHOGENESIS OF CLUSTER HEADACHE}

The pathogenesis of cluster headache is not fully under$\operatorname{stood}^{(23)}$. The hypothalamus is considered to play a major role in generating the episodes. The peripheral nervous system is probably also involved ${ }^{(24)}$. Severe pain is caused by the stimulation of the ophthalmic nerve (the first and the smallest branch of the trigeminal nerve - V1), while activation of the cranial parasympathetic part of the facial nerve induces autonomic symptoms ${ }^{(24,25)}$.

\section{THE SYMPTOMS OF PRIMARY HEADACHES}

Headaches (tension-type, migraine and cluster headaches) produce characteristic symptoms, identification of which is essential for the diagnosis. According to the International Headache Society ${ }^{(3)}$, TTHs are classified as:

1. infrequent episodic TTH - at least the last 10 episodes with a frequency of less than 1 episode per month $(<12$ days a year);

2. frequent episodic TTH - at least 10 episodes with an average frequency of 1-14 episodes per month for more than 3 months, for at least 12 days but not more than 180 days per year;

3. chronic TTH - persisting for at least 15 days per month over at least 3 months and for more than 180 days per year.

The diagnostic criteria for the diagnosis of TTH have been also set:

1. headache lasting from 30 minutes to 7 days;

2. at least 2 of the following symptoms: bilateral, pressing, tightening (nonpulsating) quality, mild or moderate intensity, the pain does not worsen with routine physical activity;
3. both symptoms: no nausea or vomiting (lack of appetite may occur), sensitivity to light or sound, or the presence of one of these symptoms;

4. pain not attributed to any other disorder ${ }^{(3)}$.

Tension-type headaches can occur with and without periosteal tenderness (increased periosteal tenderness upon palpation).

TTH usually lasts from 30 minutes to up to 7 days. Unlike migraine, TTH is not paroxysmal in nature, but it grows slowly and is not preceded by prodromal symptoms ${ }^{(3,21)}$. It is usually described as continuous and persistent pain, with the feeling of a clamp squeezing the skull or tightening around the head. It is mild to moderate, and rarely reaches the intensity of migraine pain. Despite the presence of symptoms, patients are able to perform their daily activities, and physical activity generally does not exacerbate the pain. TTH attacks are not preceded by aura. Nausea is extremely rare and occurs only in cases of very severe pain ( $0.5 \%$ of patients). The accompanying symptoms, such as photophobia, sleep disturbances, hypersensitivity to noise, chronic fatigue, decreased appetite, may occur, but are not considered specific. If present, they are much milder than the ones in migraine and do not correlate with the severity of pain. Most TTHs are bilateral, usually involving the entire head or the temples. Migraine headaches, on the other hand, initially effect one hemisphere, and extend to the entire head over time $e^{(1,8,19)}$. Epidemiological data show that migraine affects about $10 \%$ of the Popish population. Migraine can affect people of all ages, with peaks in prevalence between $30 \mathrm{~s}$ and $50 \mathrm{~s}^{(26)}$. The global prevalence is comparable and ranges from $3 \%$ to up to $20 \%{ }^{(27)}$. Several types of migraine have been distinguished: migraine without aura, which is the most common type of migraine (80-90\% of cases), migraine with aura (10-15\%), chronic migraine and episodic migraine ${ }^{(21)}$. The International Headache Society proposed simplified diagnostic criteria for migraine. These criteria include frequent headaches lasting 7-72 hours, without abnormalities in physical examination and in the absence of other causes of pain. Furthermore, at least 2 of the following pain qualities are necessary: unilateral, pulsating, moderate to severe, and aggravated by body movement. The pain is accompanied by at least one of the following: nausea and/or vomiting, photophobia and phonophobia ${ }^{(3,5)}$.

The clinical picture of aura in migraine is very diverse. In most cases, it precedes the onset of pain, but it may occur simultaneously. Aura is manifested by fully reversible focal symptoms (visual disturbances - lines, dots, circles or flashes of light moving in the field of vision, impaired sensation, motor or speech dysfunctions, or brainstem symptoms, e.g. dizziness, impaired balance, problems with eye movements, including nystagmus), developing gradually and lasting 5-60 minutes, which are followed by the headache ${ }^{(28)}$.

Migraine pain is described as pulsating, intense and often limited to one side of the head (hemicrania). It is aggravated by even the slightest physical activity. Prodromal symptoms, such as stiff neck, problems focusing, excessive yawning, 
scotomas, hemianopia, hemiplegia, and speech disorders, are predicative of migraine onset. The attacks are spontaneous and recurrent. They can also be caused by characteristic, though often unique and variable factors, such as: weather changes, wind, sleep disturbances, certain food products (chocolate, cheese, red wine in particular), as well as medications (e.g. nitrates, oral contraceptives). Some migraine patients experience episodes of tension-type headache between migraine attacks. Both TTH and migraine can evolve into a form where pain occurs almost every day ${ }^{(5,7,18)}$.

Cluster headache is the most severe type of primary headache $^{(24,25)}$. The affected patients experience severe, one-sided pain, which may be accompanied by anxiety and agitation $^{(24,25)}$. Suborbital, frontal and temporal locations are typical. Its specific symptoms include eyelid oedema, conjunctival injection, lacrimation, runny nose or nasal congestion. The pain persists for several to 180 minutes, with mean duration of 45-60 minutes $^{(23)}$.

According to the International Society of Headache, cluster headache is classified as:

1. Episodic cluster headache - more common, accounting for $85 \%$ of cases. It is characterised by attacks (clusters) occurring every day over the period of several weeks or months. Pain occurs several times a day, especially at night. There are remission periods between the clusters, which may last from one month to several years ${ }^{(29)}$.

2. Chronic cluster headache - the attacks recur for over a year. There is no remission or remission that lasts less than three months. This cluster headache subtype can develop from an episodic subtype or be chronic already from the outset ${ }^{(23,29,30)}$.

According to ICHD-3 beta, the following criteria must be met to diagnose cluster headache:

1. at least five attacks fulfilling criteria $2-4$;

2. severe or very severe unilateral orbital, supraorbital and/or temporal pain lasting 15-180 minutes (when untreated);

3. either or both of the following: a) at least one of the symptoms (ipsilateral to the headache): conjunctival injection and/or lacrimation, nasal congestion and/or rhinorrhoea, eyelid oedema, forehead and facial sweating, miosis and/or ptosis, b) restlessness or agitation;

4. occurring with a frequency of 1-8 times per day ${ }^{(3)}$.

\section{DIFFERENTIAL DIAGNOSIS OF HEADACHE}

Differential diagnosis is primarily based on thorough medical interview assessing subjective pain sensations. Migraine and TTH are more common in women as opposed to cluster headache, which is more common in men. No influence of social, economic or intellectual factors on TTH and migraine has been shown. TTH affects all age groups but is most common among middle-aged individuals ${ }^{(1,2)}$.

The duration of pain is the differentiating factor: $30 \mathrm{~min}$ utes to 7 days for TTH, 7-72 hours for migraine, and 15 minutes to 3 hours for cluster headache ${ }^{(3,5,7,23)}$. Each of these conditions has its own characteristics. TTH is a pressure or squeezing pain that is not exacerbated by physical activity. Migraine is a throbbing pain that interferes with daily activities and is aggravated by physical exercise. Cluster headache is a very severe, excruciating pain.

TTH is usually bilateral, while migraine and cluster headache are unilateral, with the latter one usually located superorbitally and temporally ${ }^{(1,18,24)}$.

Among the discussed primary headaches, the most characteristic symptoms are seen in cluster headache, and these include conjunctival injection, lacrimation, nasal congestion, runny nose, facial sweating, miosis, ptosis and eyelid oedema $^{(24,25)}$. Nausea and, sometimes, vision or hearing impairment may occur in TTH and migraine ${ }^{(10,20)}$.

The circumstances of pain are also a differentiating factor. A migraine attack may be triggered by factors such as red wine, cheeses, exposure to specific smells (e.g. cigarette smoke $)^{(31)}$, while TTH may be caused by emotional stress ${ }^{(10)}$. Alcohol can be a trigger for cluster headache ${ }^{(32)}$.

The fact that patients with migraine develop symptoms typical of migraine as well as yawning, nausea, vomiting and arterial hypotension after administration of dopaminergic agonists, which is not observed in TTH patients, may be helpful in the diagnosis. Dopaminergic antagonists are therefore beneficial treatment for migraine but fail to alleviate the TTH symptoms ${ }^{(21)}$. Ergot preparations do not affect the course of TTH; however, tricyclic antidepressants have been shown to be effective ${ }^{(8)}$. Sumatriptan is used in the treatment of cluster headache, but it can also relieve or alleviate migraine ${ }^{(30)}$. This type of pain is also relieved by inhaling pure oxygen. Recent studies recommend higher doses of pure oxygen, i.e. $7-10 \mathrm{~L} / \mathrm{min}$ for 15 minutes $^{(23,33)}$.

No abnormalities other than the tenderness at the site of head and neck muscle attachments in some patients with TTH are found in physical examination. So far, no specific biochemical markers of TTH have been identified; however, Ashina et al. have shown an increase in CGRP levels in patients with this type of primary headache ${ }^{(24,34)}$. In the case of the presence of non-specific symptoms, it is useful to exclude masticatory dysfunction, which indirectly points to migraine ${ }^{(30)}$.

\section{CONCLUSIONS}

The headaches described in this paper have been classified by the International Headache Society as primary headaches, which are highly common in the general population. Accurate differential diagnosis and interdisciplinary cooperation between dentists, neurologists, and physiotherapists are necessary to exclude other causes of headache (secondary headaches) and to establish an accurate diagnosis that will allow to implement effective treatment.

\section{Conflict of interest}

The authors do not declare any financial or personal links to other persons or organisations that could adversely affect the content of this publication or claim rights thereto. 


\section{References}

1. Chochowska M, Klonowska J, Ogrodowczyk R et al.: Napięciowe bóle głowy a zespół bólu mięśniowo-powięziowego. Część I. Klasyfikacja, etiopatogeneza, kryteria diagnostyczne. Hygeia Public Health 2015; 50: 283-287.

2. Rasmussen BK, Lipton RB: Epidemiology of tension-type headache. In: Olesen J, Tfelt-Hansen P, Welch MK (eds.): The Headaches. Lippincott Williams \&Wilkins, Philadelphia 2000: 545-550.

3. Headache Classification Committee of the International Headache Society (IHS): The International Classification of Headache Disorders, $3^{\text {rd }}$ edition (beta version). Cephalalgia 2013; 33: 629-808.

4. Dodick DW: Clinical practice. Chronic daily headache. N Engl J Med 2006; 354: 158-165.

5. Rożniecki JJ, Stępień A, Domitrz I: Leczenie migreny przewlekłej zalecenia opracowane przez Grupę Ekspertów Polskiego Towarzystwa Bólów Głowy i Sekcji Badania Bólu Polskiego Towarzystwa Neurologicznego na podstawie międzynarodowych zaleceń i najnowszej literatury. Pol Przegl Neurol 2018; 14: 60-66.

6. Haut SR, Bigal ME, Lipton RB: Chronic disorders with episodic manifestations: focus on epilepsy and migraine. Lancet Neurol 2006; 5: 148-157.

7. Boćkowski L, Sendrowski K, Śmigielska-Kuzia J: Doraźne leczenie napadów migrenowych i stanu migrenowego u dzieci i młodzieży. Neurol Dziec 2011; 20: 81-87.

8. Stępień A: Napięciowy ból głowy. Borgis - Nowa Medycyna $2003 ; 2$.

9. Russell MB: Epidemiology and genetics of cluster headache. Lancet Neurol 2004; 3: 279-283.

10. Waś A, Tucholska S: Napięciowe bóle głowy - aspekty psychologiczne. Neurol Dziec 2011; 20: 115-119.

11. Torelli P, Abrignani G, Castellini P et al.: Human psyche and headache: tension-type headache. Neurol Sci 2008; 29 Suppl 1: S93-S95.

12. Montagna P: Migraine genetics. Expert Rev Neurother 2008; 8: 1321-1330.

13. Goadsby PJ, Holland PR, Martins-Oliveira M et al.: Pathophysiology of migraine: a disorder of sensory processing. Physiol Rev 2017; 97: 553-622.

14. De Fusco M, Marconi R, Silvestri L et al.: Haploinsufficiency of ATP1A2 encoding the $\mathrm{Na}^{+} / \mathrm{K}^{+}$pump a2 subunit associated with familial hemiplegic migraine type 2. Nat Genet 2003; 33: 192-196.

15. Blumenfeld AE, Victorio MC, Berenson FR: Complicated migraines. Semin Pediatr Neurol 2016; 23: 18-22.
16. Albury CL, Stuart S, Haupt LM et al.: Iron channelopathies and migraine pathogenesis. Mol Genet Genomics 2017; 292: 729-739.

17. Asghar MS, Hansen AE, Amin FM et al.: Evidence for a vascular factor in migraine. Ann Neurol 2011; 69: 635-645.

18. Zgorzalewicz M: Patomechanizm migrenowych bólów głowy. Neurol Dziec 2005; 14: 7-14.

19. Bernstein C, Burstein R: Sensitization of the trigeminovascular pathway: perspective and implications to migraine pathophysiology. J Clin Neurol 2012; 8: 89-99.

20. Schulte LH, Jürgens TP, May A: Photo-, osmo- and phonophobia in the premonitory phase of migraine: mistaking symptoms for triggers? J Headache Pain 2015; 16: 14.

21. Linde M: Migrena: współczesne kierunki leczenia. Pol Przegl Neurol 2008; 4 Suppl C: C1-C13.

22. Louis ED, Mayer SA, Rowland LP: Merritt Neurologia. Vol. 1, Edra Urban \& Partner, Wrocław 2017.

23. Prusiński A: Klasterowy ból głowy. Neurol Prakt 2012; 6: 20-24.

24. Hoffmann J, May A: Diagnosis, pathophysiology, and management of cluster headache. Lancet Neurol 2018; 17: 75-83.

25. May A: Cluster headache: pathogenesis, diagnosis, and management. Lancet 2005; 366: 843-855

26. Stępień A, Prusiński A, Suwała A: Wybrane dane epidemiologiczne występowania migreny w Polsce. Ból 2003; 4: 9-12.

27. Natoli JL, Manack A, Dean B et al.: Global prevalence of chronic migraine: a systematic review. Cephalalgia 2010; 30: 599-609.

28. Eriksen MK, Thomsen LL, Andersen I et al.: Clinical characteristics of 362 patients with familial migraine with aura. Cephalalgia $2004 ; 24: 564-575$.

29. Lipton R, Bigal ME, Steiner TJ et al.: Klasyfikacja samoistnych bólów głowy. Neurology 2004; 63: 427-435.

30. Osiewicz MA, Pytko-Polończyk J: Role of a dentist in diagnosing primary headaches. J Stoma 2012; 65: 555-566.

31. Onderwater GLJ, van Oosterhout WPJ, Schoonman GG et al.: Alcoholic beverages as trigger factor and the effect on alcohol consumption behavior in patients with migraine. Eur J Neurol 2019; 26: 588-595.

32. Dueland AN: Headache and alcohol. Headache 2015; 55: 1045-1049.

33. Cohen AS, Burns B, Goadsby PJ: High-flow oxygen for treatment of cluster headache: a randomized trial. JAMA 2009; 302: 2451-2457.

34. Ashina M, Hansen JM, Do TP et al.: Migraine and the trigeminovascular system - 40 years and counting. Lancet Neurol 2019; 18: 795-804. 